\title{
A review of aluminium phosphide poisoning and a flowchart to treat it
}

\author{
Behrooz Hashemi-Domeneh ${ }^{1,2}$, Nasim Zamani ${ }^{1,2}$, Hossein Hassanian-Moghaddam ${ }^{1,2}$, Mitra \\ Rahimi $^{1,2}$, Shahin Shadnia ${ }^{1,2}$, Peyman Erfantalab ${ }^{1,2}$, and Ali Ostadi ${ }^{1,2}$ \\ Toxicological Research Center, Department of Clinical Toxicology, Loghman-Hakim Hospital, Shahid Beheshti \\ University of Medical Sciences ${ }^{1}$, Excellence Center of Clinical Toxicology, Iranian Ministry of Health ${ }^{2}$, Tehran, Iran
}

[Received in February 2016; CrossChecked in February 2016; Accepted in September 2016]

The use of pesticides such as aluminium phosphide (AlP) has increased in the recent years and improved the quantity and quality of agricultural products in a number of developing countries. The downside is that AlP causes severe chronic and acute health effects that have reached major proportions in countries such as India, Iran, Bangladesh, and Jordan. Nearly 300,000 people die due to pesticide poisoning in the world every year. Poisoning with AlP accounts for many of these deaths. Unfortunately, at the same time, there is no standard treatment for it. The aim of this article is to give a brief review of AlP poisoning and propose a treatment flowchart based on the knowledge gained so far. For this purpose we reviewed all articles on the management of AlP poisoning published from 2000 till now. Using a modified Delphi design, we have designed a handy flowchart that could be used as a guide for AlP poisoning management of patients in emergency centres.

KEY WORDS: emergencies; literature review; pesticides; poisoning management

Pesticide use has increased the quantity and quality of agricultural products in a number of developing countries. Although its wise use may improve the quality of life and livelihood of their residents, improper use may cause severe chronic and acute poisoning. In fact, nearly 300,000 people in the world die every year due to pesticide poisoning (1).

Metal phosphides make a large proportion of the pesticides/fumigants that are currently being used. The use of aluminium, magnesium, and calcium phosphides has become popular in developing countries mainly because they are potent, cheap, and have no undesirable effects on agricultural products. Yet, the risk of mortality associated with phosphide poisoning in humans ranges between $30 \%$ and $100 \%$ (2).

Aluminium phosphide (AlP) is used for crop protection in storage and transport such as silos, ships, and trains (3). It is quite common in Iran (especially northern Iran) in the form of tablets (hence the common term "rice tablets") due to low cost, high potency, and ready availability, but so is the risk of poisoning and death. Northern Iranian provinces report a rather high AlP poisoning rate (3), for which reason Iran has been trying to control AlP production and purchase, but the tablets are still being smuggled into the country and available to the lay people at low prices.

Current figures say that AlP is one of the most common causes of poisoning deaths in India, Sri Lanka, Iran, Oman,

Correspondence to: Nasim Zamani, MD, Department of Clinical Toxicology, Loghman-Hakim Hospital, Karegar Street, Tehran, Iran, E-mail: nasim.zamani@gmail.com and Morocco (4-8) but not in European and North American countries $(9,10)$. Reports of mortality due to AlP poisoning vary across the world. Between 1997 and 2003, UK reported only 93 cases of AlP poisoning, all of them accidental, and only one resulted in a death (4). In Germany, between 1983 and 2003, only 188 cases of AlP poisoning were reported, $65 \%$ of which accidental and mainly inhalational. They had mainly caused transient irritation of the gastrointestinal and respiratory system and none resulted in a death. The remaining, intentional poisonings caused two deaths (11).

By contrast, AlP poisoning caused 146 deaths in Iran between 2000 and $2007(8,12)$. According to Hosseinian et al. (13), more than $90 \%$ of these poisonings are suicidal. In Tehran it seems to be the most common suicide agent (14), especially in people below 30 years of age. The mortality rate ranges between $18.6 \%$ and $24 \%$ and is higher in the rural areas (15).

In contact with water, an AlP tablet releases deadly phosphine gas $\left(\mathrm{PH}_{3}\right)$, which has drawn interest for its use as a chemical weapon (4). While the danger of AlP poisoning is obvious, this can not be said for its treatment. AlP has no specific antidote, and only through shared experience can we increase the odds of survival by improving the management of AlP poisoning. (8). This article is one such attempt to gather recent knowledge in one place and suggest a management flowchart that perhaps best suits the circumstances in Iran and countries with similar issues and healthcare. 


\section{Literature search and data pooling}

We searched PubMed, Google Scholar, and Scopus for all articles on AlP poisoning management published from 2000 to date. The key words we used were "aluminium phosphide", "poisoning", "toxicity", "treatment", and "management". We reviewed the abstracts of recovered articles, looking specifically for those suggesting treatment for AlP poisoning. Duplicate articles, articles that did not meet the above criteria, and articles that did not add new data were excluded. The final pool of articles after exclusion consisted of seven reviews, 44 original articles, 33 case reports, three letters, one textbook, and five web references.

All selected articles were reviewed by the first author for original human data about the toxic effects of AlP and its management and the pooled data were discussed by all authors at six sessions. The final AlP poisoning management flowchart was designed by the corresponding author and reviewed and endorsed by six authors.

\section{POOLED FINDINGS}

\section{Chemistry}

Aluminium phosphide (AlP) comes as a dark grey or yellow crystal and AlP tablets are available under a variety of trade names, such as Phosfume, Synfum, Celphos, Phostoxin, Quickphos, Phostek, Chemfume, Degesch, Talunex, Alphosm, and Delicia (16). A three-gram tablet can release almost one gram of phosphine gas in contact with water. In Iran, the AlP tablet is marketed under the trade name of Phostoxin and contains aluminium phosphide, urea, and ammonium carbamate. Phosphine gas is flammable (16-20). To prevent spontaneous combustion the tablet should also contain ammonium carbamate at the 56:44 ratio of AlP and ammonium carbamate, respectively (18).

In contact with water, AlP tablet produces phosphine, ammonia, and $\mathrm{CO}_{2}$. Contact with acids may even increase the release of $\mathrm{PH}_{3}(21)$. Phosphine gas $\left(\mathrm{PH}_{3}\right)$ has a molecular weight of $34 \mathrm{Da}$. It is colourless, flammable, has the odour of spoiled fish (density: $1.52 \mathrm{~g} \mathrm{~L}^{-1}$ ), and is detectable at concentrations of $2 \mathrm{mg} \mathrm{L}^{-1}(2 \mathrm{ppm})$ or more. The spoiled fish odour comes from the impurities such as diphosphine $\left(\mathrm{P}_{2} \mathrm{H}_{4}\right)$, methane, arsine, and extracted hydrogen and phosphines $(3,22)$.

\section{Toxicokinetics}

Absorption: After ingestion, phosphine will be released due to contact between AlP and water/acid in the gastrointestinal (GI) tract. Some phosphide may be absorbed by the GI tract without hydrolysis and convert into phosphine. Phosphine gas can rapidly be absorbed by the lungs and GI tract. Absorption through skin and eyes is not common but may happen (23).
Distribution: After ingestion, phosphine concentration increases in the blood and liver. This small molecule can easily be distributed in all tissues $(24,25)$.

Metabolism and elimination: Metal phosphides change to phosphine due to hydrolysis. The most important urine metabolite of phosphine is hypophosphite, but urine can also contain phosphate and phosphite. Phosphine itself is eliminated by exhalation (26). Aluminium phosphide may be eliminated in the urine unchanged.

\section{Toxicodynamics}

Most of the toxic effects of metal phosphides are owed to $\mathrm{PH}_{3}$, which is a protoplasmic poison that interferes with the function of the cellular enzymes and proteins. According to some authors $(27,28)$, the mechanism of its toxicity is electron transfer blockage and non-competitive blockage of cytochrome $\mathrm{C}$ oxidase, which inhibits oxidative phosphorylation and, in turn, cellular respiration and activation of peroxide radicals. Phosphine can inhibit catalase and deplete glutathione, which may result in cellular wall and canal dysfunction as well $(29,30)$.

According to Proudfoot (31), studies have shown that phosphine impairs cellular respiration. It inhibits the entrance of amino acids into the cycle of myocardial protein synthesis and also inhibits cytochrome $\mathrm{C}$ oxidase in cardiac cells. According to Anand et al. (32), these changes in the mitochondria and myocardial proteins impair cellular permeability to sodium, potassium, magnesium, calcium, and other ions and change cardiac cell wall potential. Phosphine-induced pathophysiological changes are more prominent in the myocardium, pulmonary cells, and tiny peripheral vessels (26).

Both AlP and phosphine inhibit cholinesterase, but this inhibition is unlikely to be clinically relevant (33). Another toxic action of phosphine is that it changes the capacity of haeme. In vitro studies show that humans and rats can absorb unhydrolysed aluminium phosphide salt, which keeps reacting with free haemoglobin and haemoglobin in normal red blood cells (RBCs) to produce haemichrome, a derivative of methaemoglobin $(31,34)$.

Levels of carbon monoxide, which can be established by CO-oximetry, can help diagnosis and prognosis of AlP poisoning. Namely, phosphine may affect oxyhaemoglobin that interacts with $\mathrm{CO}$ and cause dyshaemoglobinemia, which can yield high $\mathrm{CO}$ findings (35).

Considering that phosphine produces free oxygen radicals in body tissues, it has been shown that organs with a higher need for oxygen (heart, lung, kidney, and liver) are more sensitive to the damage induced by phosphine gas, which is compatible with the post-mortem histopathological changes in these organs. In addition, Heinz bodies, which are indicative of the destruction of haemoglobin in vitro, increase to $1.25 \mu \mathrm{g} \mathrm{mL}^{-1}$ in poisoned patients (36). 


\section{Toxic levels}

The lethal dose of AlP in a normal $70-\mathrm{kg}$ adult has been reported to be $500 \mathrm{mg}$ (37). In the work place, air phosphine level of $50 \mathrm{mg} \mathrm{L}^{-1}(50 \mathrm{ppm})$ may be dangerous for health, and 400-600 $\mathrm{mg} \mathrm{L}^{-1}$ (400-600 ppm) may cause death in 30 minutes (38).

\section{CLINICAL MANIFESTATIONS}

\section{Acute poisoning due to ingestion}

The first signs and symptoms of poisoning manifest themselves in 10-15 min, progress very fast (32), and affect the cardiovascular and respiratory systems. If the tablet is ingested, GI irritation can also be detected. Early signs include nausea and vomiting, epigastric and retrosternal pain, dyspnoea, anxiety, irritability, and garlic or spoiled fish odour from the patients' breath can be detected at the early stages of toxicity. This odour can also be detected after inhalation (16).

Early gastrointestinal signs and symptoms include haematemesis, vomiting, and epigastric pain. Dysphagia is a common but delayed complication. Endoscopy usually shows destructive lesions of the oesophagus and stomach, stomach lesions, duodenal erosions, and oesophageal obstruction or fistula (21).

Poisoning manifestations of the central nervous system generally include irritability, anxiety, dizziness, ataxia, numbness, paraesthesia, and tremor. However, these signs and symptoms are not prominent, unless important complications such as hypoxia or hypotension occur. Delayed and severe neurological signs include delirium, seizure, and coma (39). Persistent shock can cause drowsiness, delirium, and coma.

The most common hepatotoxicity findings in patients who ingested AlP tablets are elevated aspartate transaminase and alanine transaminase (40-43). Jaundice, if manifested, may be a sign of liver impairment (40). In deceased patients the most common histopathological findings are cytoplasmic vacuolation of the hepatocytes and sinusoidal congestion (44).

The most common respiratory signs and symptoms are tachypnoea, dyspnoea, crepitation, and rhonchi. Respiratory distress syndrome and pulmonary oedema are common in adult patients and accompany the accumulation of bloody or full-protein liquids in the pleural space (32).

Cardiac signs and symptoms include increased size of the ventricles, left ventricular and septal hypokinesia, akinesia, decreased cardiac output, severe hypotension, increased systemic venous pressure, normal capillary wedge pressure, and inappropriate systemic vasoconstriction (21). Electrocardiographic (ECG) changes depend on the time elapsed since AlP ingestion. Sinus tachycardia is prominent within the first three to six hours, followed by conductive delays and arrhythmias from hours six to twelve (45). The most common arrhythmias are supra-ventricular tachycardia (46\%), ventricular tachycardia $(40 \%)$, ventricular fibrillation (23\%), and atrial flutter and fibrillation (20\%) (46). Post-mortem findings show cardiac failure, severe and persistent hypotension, heart congestion, subendocardial infarction, pericarditis, cardiac fibre detachment due to oedema, fibre destruction, nonspecific vacuolation of the myocytes, local necrosis, neutrophil infiltration, and eosinophilia (40, 41, 47-50).

Electrolyte abnormalities include high or low sodium, potassium, and magnesium. Hypocalcaemia may also be detected. Hypokalaemia may precede or follow vomiting. Hyperkalaemia, hypernatremia, and hyponatremia are associated with poorer prognosis (49). Hyper- or hypoglycaemia may also occur $(40,48,50)$. Changes in the serum level of magnesium, calcium, phosphate, citrate, and cortisol may increase serum glucose levels, which is associated with poorer prognosis (25).

Other uncommon manifestations include hepatitis, pancreatitis, ascites, myocardial infarction, acute pericarditis, pleural effusion, acute tubular necrosis (ATN), adrenocortical congestion with bleeding or necrosis, diffuse intravascular coagulation (DIC), rhabdomyolysis, and methaemoglobinaemia $(3,31,42)$. Oesophageal stricture and oesophagotracheal fistula are two delayed complications (51-55). Most deaths occur within the first 12-24 h due to cardiac arrest (47). Deaths occurring after $24 \mathrm{~h}$ are often related to hepatic failure (32).

\section{Acute poisoning due to inhalation}

After inhaling small amounts of phosphine gas, patients generally experience respiratory tract irritation and dyspnoea (3). Other manifestations include dizziness, chest tightness, headache, nausea and vomiting, diarrhoea, ataxia, numbness, paraesthesia, tremor, muscular weakness, and diplopia $(6,38)$. Inhalation of high amounts of the gas can lead to cardiac failure, acute respiratory distress syndrome (ARDS), dysrhythmia, seizure, coma, and delayed manifestations such as liver and kidney toxicity $(6,38)$.

\section{Chronic poisoning}

Patients with chronic phosphine exposure, usually those who work in silos, have manifestations such as cough, dyspnoea, chest pain, drowsiness, loss of appetite, and epigastric pain (56). Chronic exposure to low levels of phosphine may induce toothache and mandibular swelling and necrosis (phossy jaw). Chronic dermal exposure to $0.4 \mathrm{mg} \mathrm{L}^{-1}(0.4 \mathrm{ppm})$ of phosphine gas may cause dermal congestion and sensitivity $(56,57)$.

\section{Laboratory findings}

Diagnostic laboratory tests that can predict the outcome are mandatory for the management of AlP poisoning. Generally these include ECG, cardiac monitoring, chest 
$\mathrm{X}$-ray, blood sugar, arterial or venous blood gas analysis (ABG or VBG), serum electrolytes, complete blood count (CBC), and liver and kidney function tests. Hypo- and hypermagnesemia are associated with cardiotoxicity and vast myocyte destruction (3). Poisoned patient may have high, low, or even normal levels of magnesium $(40,49,58)$. $\mathrm{CBC}$ can show low white and red blood cell counts. Intravascular haemolysis, methaemoglobinaemia, or microangiopathic haemolysis are less common complications of AlP poisoning (34, 58- 60). Serum sodium and potassium may either be high or low. Hypokalaemia is generally detected after tablet ingestion and is probably caused by vomiting or catecholamine release (31). Hypoglycaemia can be due to gluconeogenesis, glycogenolysis, or adrenal insufficiency. Hypoglycaemia is common and can be severe and persistent (57). It is also associated with a poorer outcome $(25,60,61)$. ABG analysis can detect metabolic acidosis or mixed metabolic acidosis and respiratory alkalosis (31).

Chest x-ray generally shows pulmonary oedema, pleural effusion, and sub-pericardial bleedings.

ECG changes include sinus tachycardia, ST changes, inverted T, myocardial infarction, AV block (especially the right bundle branch block), and complete heart block (31, 62 ) in addition to the previously mentioned complications. If the patient survives the first 24 hours, ECG changes will normalize in 10-25 days. Life-threatening changes can be detected by the ECG in as many as $50 \%$ of the patients. (41).

\section{Biosample testing for $\mathrm{PH}_{3}$}

Phosphine is rapidly oxidised to phosphate and hypophosphite and is not tested for in clinical assessments (19). Identifying its presence in tissue is not necessary for the diagnosis of AlP poisoning.

However, qualitative analysis of $\mathrm{PH}_{3}$ is important for forensic purposes. Forensic evaluation includes the analysis of expiratory air (50\% of the AlP-poisoned patients have positive expiratory tests) (3), stomach content (vomits and/ or gastric lavage), which can be collected in clean glass samplers, urine (only for $\mathrm{PH}_{3}$ metabolites due to rapid oxidation of the gas), and liver. Heated in acidic environment, liver tissue releases $\mathrm{PH}_{3}$ in the tissue matrix, which makes it a valuable sample for post mortem identification of phosphine. Blood, however, is not suitable due to the oxidative metabolism of phosphines (36).

\section{Routine methods of AlP detection and quantification}

Phosphine is routinely detected in biosamples by chemical qualitative colour tests such as silver nitrate $(0.1 \mathrm{~N}$ or $\left.16.987 \mathrm{~g} \mathrm{~L}^{-1}\right)$, mercury chloride in ethanol, acidic potassium permanganate $\left(0.1 \mathrm{~N}\right.$ or $\left.79.017 \mathrm{~g} \mathrm{~L}^{-1}\right)$, or $0.5 \%$ mercury diethylthiocarbamate. The sample is heated in acidic environment to release $\mathrm{PH}_{3}$, which interacts with the chemical and generates a specific colour.
Detection of $\mathrm{PH}_{3}$ with silver nitrate paper is perhaps the most common and valuable in clinical and forensic tests and can be used on biosamples such as expiratory air and stomach content. Silver nitrate reacts with $\mathrm{PH}_{3}$ and changes the colour of the paper to dark grey or black (63). The method is sensitive enough to detect $\mathrm{PH}_{3}$ at concentrations as low as $0.05 \mathrm{mg} \mathrm{L}^{-1}(0.05 \mathrm{ppm})$.

Less common tests use ammonium, arsine, and ammonium molybdate as detectors. The first two are used on expiratory air samples (26) but are seldom used for clinical testing over validity issues. The ammonium molybdate test is used on stomach content.

Potentiometry, in turn, is a semi-quantitative test used to determine the concentration of $\mathrm{PH}_{3}$. $\mathrm{PH}_{3}$ reacts with mercury chloride $\left[\mathrm{PH}_{3}+3 \mathrm{HgCl}_{2} \rightarrow \mathrm{P}(\mathrm{HgCl})_{3}+3 \mathrm{HCl}\right]$ to produce a series of changes in the oxidation-reduction potential and consequently in the electrical conduction of electrochemical cells. The concentration of $\mathrm{PH}_{3}$ can also be calculated from $\mathrm{HCl}$ released from sodium hydroxide (64). Currently the most sensitive and specific quantification method is chromatography with a nitrogen-phosphorus detector, as it can measure even the lowest levels of $\mathrm{PH}_{3}$ in the air (65).

\section{Differential diagnosis}

The signs and symptoms of mild poisoning are similar to the signs and symptoms of upper respiratory infections. In severe cases of poisoning, contact with $\mathrm{PH}_{3}$ can be misdiagnosed with cardio-pulmonary oedema, viral, and bacterial pneumonia, or ARDS due to other causes (32). Signs and symptoms of poisoning with zinc phosphide can be similar to AlP poisoning, but are usually slower to manifest themselves, and zinc phosphide poisoning has a lower mortality rate $(66,67)$.

\section{Treatment of acute poisoning}

The proposed AlP poisoning treatment flowchart (Figure 1) is mostly intended for Iran and can be used as a unified method throughout the country.

After the presentation of a patient with suspected history of AlP poisoning, the first step is to diagnose if the patient has really been exposed to AlP using the above-mentioned diagnostic tests. Whoever of the medical staff is checking the patient should wear a full-face mask and rubber gloves. Bear in mind that masks with tiny pores cannot prevent $\mathrm{PH}_{3}$ exposure (65). If the patient's clothes are contaminated, they should be taken off. Contaminated skin and eyes should be thoroughly washed (3). The vomit can contain $\mathrm{PH}_{3}$ and can be dangerous to others, so it should be cleaned and disposed of. Whoever does the cleaning should be warned about the dangers. In inhalational exposures the patient should immediately be removed from the contaminated environment, his/her clothes changed, and his/her skin washed, taking recommended precautions. 


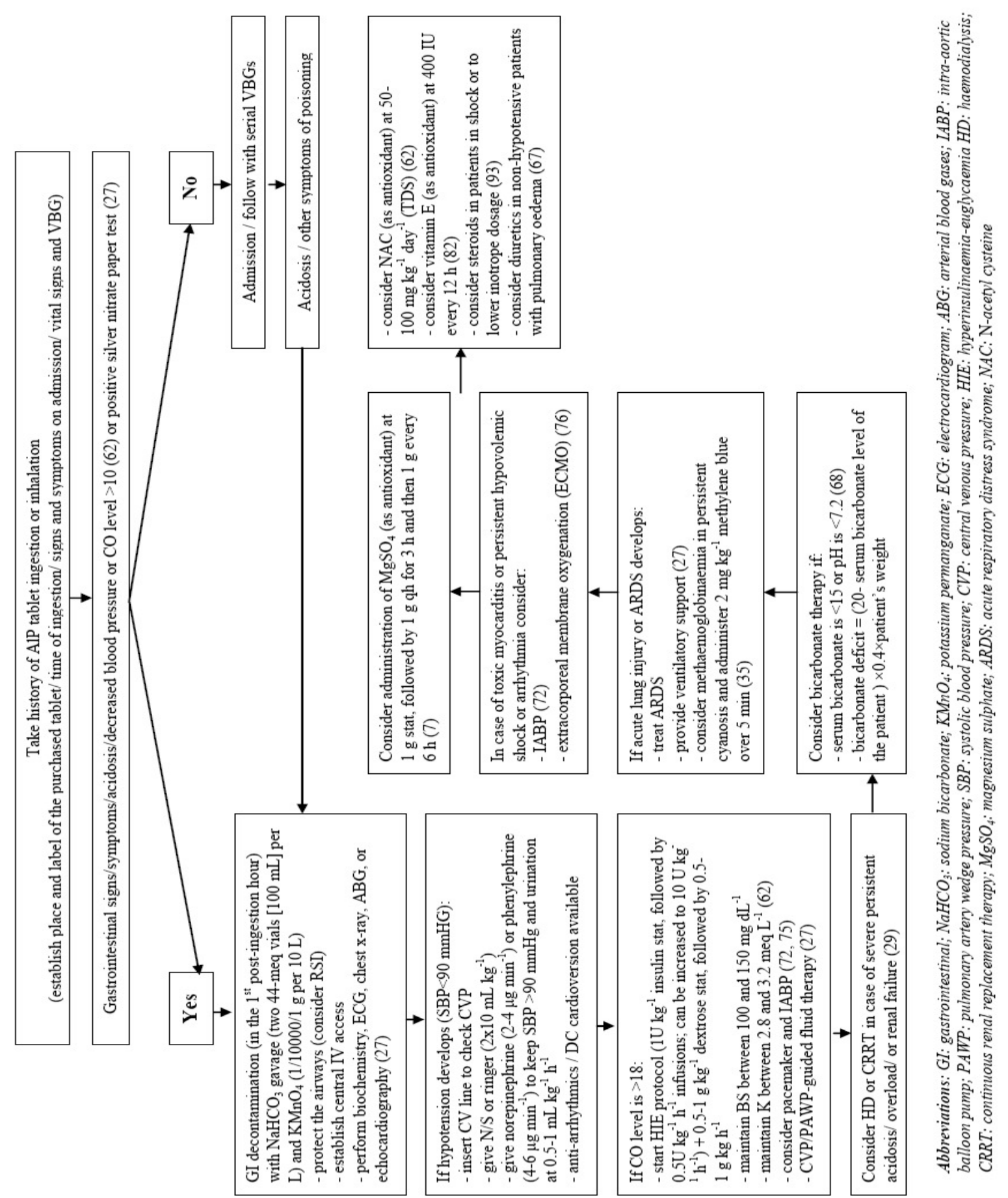


As there is no specific antidote for AlP poisoning, the cornerstone of therapy is supportive care. Timing significantly affects the prognosis. If AlP poisoning is suspected based on the history and physical examination, treatment must not be delayed until test results are confirmed (24). Symptomatic patients should be monitored in the intensive care unit (ICU) for at least 72 hours. They should be receiving 100-percent oxygen and treated for fluid and electrolyte abnormalities. Serum calcium and magnesium and liver/kidney function tests are mandatory (68).

\section{GI decontamination}

Gastrointestinal decontamination is efficient within the first hour after rice tablet ingestion. As stomach acid increases the conversion of AlP to $\mathrm{PH}_{3}$, treatment with 3-5\% sodium bicarbonate can help, although its efficacy has not been proved $(26,69)$. Gastric lavage using a 1:10,000 solution of potassium permanganate oxidizes $\mathrm{PH}_{3}$ to a nontoxic phosphate. If it is administered in the first hour after ingestion, it can substantially decrease the amount of toxic $\mathrm{PH}_{3}(69,70)$.

Administration of activated charcoal $\left(1 \mathrm{~g} \mathrm{~kg}^{-1}\right.$ in children and 50-100 $\mathrm{g}$ in adults) lowers phosphide absorption and alleviates latent signs/symptoms of poisoning. Although it is useful in a patient who has recently ingested a huge amount of AlP, its efficacy is limited and is therefore not recommended for routine treatment (69).

Some recommend the use of coconut oil to accompany routine treatment $(63,70)$, as it contains saturated fatty acids and seems to reduce the release of $\mathrm{PH}_{3}$ in gastric acid. Furthermore, coconut oil seems to coat the stomach mucosa and prevent $\mathrm{PH}_{3}$ absorption. This effect was reported after co-administration of $50 \mathrm{~mL}$ of coconut oil and $50 \mathrm{~mL}$ of sodium bicarbonate (70), but there is little other research evidence to make it part of routine treatment. Vegetable oils and liquid paraffin have also been reported to prevent $\mathrm{PH}_{3}$ release from AlP in vitro, but there is only one case report to confirm it (70). Another promising treatment, according to Saidi and Shojaie (71), could be sweet almond oil, as it lowered AlP-induced death in rats, but its action has not been reported in human-beings. Hassanian-Moghaddam and Shahbazi (72) proposed the use of gastric ventilation to evacuate $\mathrm{PH}_{3}$ within minutes of rice tablet ingestion. More studies are needed to prove the efficacy of this method.

\section{Cardiovascular support}

Due to the cardiovascular effects of the toxin, ECG and cardiac monitoring are recommended in all patients. Primary resuscitation by administration of fluids and inotropes and checking central vein pressure (CVP) and pulmonary artery wedge pressure (PAWP) are also recommended (26, 73-75). Norepinephrine, phenylephrine, dopamine, or dobutamine can be used to treat hypotension and persistent shock. However, vasopressors with greater activity at beta receptors (such as dopamine and dobutamine) can cause dysrhythmias and should be used with caution (26).

Cardiac arrhythmias are generally treated by antiarrhythmic medications, direct-current defibrillation, or temporary pacemaker. Digoxin is used to stabilise the left ventricle. Earlier case reports showed that primary administration of $0.5 \mathrm{mg}$ of digoxin followed by $0.5 \mathrm{mg}$ every six hours for the first day and $0.25 \mathrm{mg}$ daily afterwards improved the patient's cardiovascular symptoms $(73,74)$. However, only a few studies have evaluated the efficacy of digoxin in the treatment of AlP poisoning, and it may be initiated in patients whose cardiac insufficiency has been confirmed by echocardiogram.

Some physicians recommend inducing hyperinsulinaemia-euglycaemia (HIE) as well as hyperventilation, as both trigger energy production from carbohydrates, reverse calcium, and improve myocyte contractions (62). Some report the use of intra-aortic balloon pump (IABP) for mechanical support of the heart in patients with toxic myocarditis, persistent shock or persistent cardiac complications of the poisoning $(72,75)$. Some persistent cases may require the implantation of a pacemaker (12). Extracorporeal membrane oxygenation is another recently suggested treatment with promising results $(75,76)$.

\section{Respiratory support}

One of the complications of AlP poisoning is the development of ARDS, which is treated as usual $(26,31)$. If the patient develops persistent cyanosis, methaemoglobinaemia should be suspected and 1-2 $\mathrm{mg} \mathrm{kg}^{-1}$ of methylene blue should be intravenously administered over five minutes (21).

\section{Other treatments}

Sodium bicarbonate is used for the treatment of acidosis. If the patient has volume overload, haemodialysis (HD) can be performed, although it cannot expel $\mathrm{PH}_{3}$ from the blood (28). Infusing the patient with 1-4 L of 5-10\% dextrose in water (DW) is recommended to maintain serum glucose in the normal range. Hypoglycaemia, hypokalaemia, and metabolic acidosis are treated as usual $(26,31)$.

Ten millilitres of $10 \%$ calcium gluconate is generally recommended to stabilise cell membranes. Administration of calcium gluconate or chloride is also recommended in case of hypocalcaemia-induced tetany $(67,77)$. Magnesium sulphate $\left(\mathrm{MgSO}_{4}\right)$ is another cell membrane stabiliser with anti-oxidant properties to mitigate the effects of free radicals released by phosphine. In general, it has been shown that this treatment can decrease AlP-related mortality by $25 \%$ (62). Different doses have been proposed for $\mathrm{MgSO}_{4}$ administration including: a) $3 \mathrm{~g}$ in $3 \mathrm{~h}$ followed by $6 \mathrm{~g}$ in $24 \mathrm{~h}$ for 3-5 days (3); b) $1 \mathrm{~g}$ as initial dose, followed by $1 \mathrm{~g}$ every hour for $2 \mathrm{~h}$ and 1-1.5 g every six hours for 5-7 days (7); and c) $1 \mathrm{~g}$ as initial dose, followed by $1 \mathrm{~g}$ for $3 \mathrm{~h}$ and then $1 \mathrm{~g}$ every six hours for five to seven days (78). 
However, due to the risk of hypermagnesemia (62), it seems that routine use of $\mathrm{MgSO}_{4}$ is not practical $(26,31)$. We therefore recommend magnesium administration with any of the above-mentioned protocols in patients with low or even normal serum magnesium levels. Daily serum magnesium monitoring can prevent hypermagnesemia during treatment.

Considering that $\mathrm{N}$-acetylcysteine (NAC) can reverse cellular glutathione and magnesium storages and acts as an antioxidant, its effects in the supportive treatment of AlP have been investigated in rats and humans. In rats, NAC prolonged survival time, stabilised blood pressure and pulse rate, and prevented oxidative stress of the myocardium (79). In humans, NAC lowered mortality, hospitalisation time, and the frequency of intubation and mechanical ventilation (80). It increased blood pressure and kept it stable within the first 24 hours. Two methods have been proposed for NAC administration:

a) intravenous (IV) infusion of $150 \mathrm{mg} \mathrm{kg}^{-1}$ in $200 \mathrm{~mL}$ of $5 \%$ DW over one hour, followed by $50 \mathrm{mg} \mathrm{kg}^{-1}$ in $500 \mathrm{~mL}$ of $5 \% \mathrm{DW}$ over four hours, and then $100 \mathrm{mg} \mathrm{kg}^{-1}$ in $1000 \mathrm{~mL}$ of $5 \%$ DW over 16 hours (37); or

b) IV infusion of $140 \mathrm{mg} \mathrm{kg}^{-1}$ followed by $70 \mathrm{mg} \mathrm{kg}^{-1}$ every four hours for 17 doses.

However, the recommended IV injection dose for routine treatment is $50-100 \mathrm{mg} \mathrm{kg}^{-1}$ three times a day (67).

Administration of vitamin E seems to prevent hepatic destruction due to lipid peroxidation by phosphine (81). This effect, however, still needs to be confirmed by future studies. Administration of vitamin C ( $1 \mathrm{~g}$ every six hours) with $1 \%$ methylene blue was successful against methaemoglobinaemia and haemolysis caused by $\mathrm{PH}_{3}$ (34). However, this treatment is generally not recommended because it may worsen patient's acidosis.

Other treatments such as melatonin, glutathione, and beta carotene have also been proposed and need further evaluation (72).

There is no report or evidence of steroid treatment efficacy in AlP poisoning, but we know that steroids act against inflammation, especially in the respiratory system (64).

Using hyperbaric oxygen prolonged survival time in rats but did not reduce mortality (82). This method has not been evaluated in humans.

Hydroxyethyl starch can stay in the vessels and prevent fluid and albumin shift to the tissues (83). However, there is no clinical information to support this effect in AlP poisoning.

Blood exchange is a questionable treatment in AlP poisoning $(84,85)$. Haemodialysis does not efficiently eliminate $\mathrm{PH}_{3}$ from blood, but can be used in patients with acute kidney failure, severe metabolic acidosis, or fluid overload (26). Administration of vasopressors, fresh blood, and bronchodilators are recommended when indicated.

If pulmonary oedema develops, and the patient is not hypotensive, diuretics can also be used.
Seizure should be treated with routine therapies, including benzodiazepines (67).

Both clinical and laboratory reports say that phosphine and aluminium inhibit acetylcholinesterase (AChE) and that pralidoxime may prove effective in restoring $\mathrm{AChE}$ activity. In rats, atropine and pralidoxime increased survival when administered five minutes after exposure to AlP. More studies are needed to prove the efficacy of oximes in the treatment of this poisoning (33). For the moment, these medications are not recommended for routine treatment.

Considering all of the above, the only recommended treatment of AlP poisoning is the general supportive one.

\section{Prognosis and long-term complications}

In ingestions of $500 \mathrm{mg}$ or more the mortality rate is 30 to $100 \%$. Most of the deaths are due to cardiovascular collapse within the first 12-24 hours $(47,62)$. After the first 24 hours, deaths are mainly due to persistent shock, severe acidosis, and ARDS (85). Fulminant hepatic failure occurs within 72 hours and is another cause of death in these patients (3). Patients who have taken lower doses, expired tablets, or tablets exposed to air have a greater chance of survival. Vomiting and early supportive care can also increase the survival rate $(12,26)$.

Poorer prognosis is associated with higher phosphine levels, no vomiting after ingestion, hyperglycaemia, hyperkalaemia, hyponatraemia, hypernatraemia, hyperuricaemia, acidosis, leukocytosis, haemoconcentration, low prothrombin time, shock, methaemoglobinaemia, abnormal ECG, need for inotropes, need for mechanical ventilation, high Simplified Acute Physiology Score (SAPS) and Acute Physiology and Chronic Health Evaluation II (APACHE II), and low Glasgow coma scale (4, 8, 25, 26, $60,86-89)$. The higher the phosphine blood level, the higher is the risk of death.

If no signs/symptoms are evident six hours after ingestion or inhalation, the patient will remain symptomfree (76). With cardio-respiratory complications the prognosis is poor (67). Most of the deaths happen in the first 24 hours, and much depends on the severity of poisoning and the time between poisoning and treatment.

Some patients reported local GI complications in the first month after poisoning including dysphagia, oesophageal stricture, and oesophagotracheal fistula (90). It is recommended that all patients undergo GI evaluation using barium swallow and endoscopy before they are released from the hospital in order to detect these complications and treat them as soon as possible (3).

Cytogenetic and genetic evaluations have shown that $\mathrm{PH}_{3}$ is not mutagenic (90).

\section{Prevention}

Access to AlP tablets should be limited and controlled, in particular their over and below-the-counter sale. Most of the victims are people with suicidal intent, and we believe 
that disseminating knowledge about this poison among lay people is not only useless but may also increase poisoning rate among people with suicidal intent. More effort should be made to disseminate and update knowledge among physicians, so that they can improve treatment and save more lives.

\section{REFERENCES}

1. Gunnell D, Eddleston M. Suicide by intentional ingestion of pesticides: a continuing tragedy in developing countries. Int J Epidemiol 2003;32:902-9. PMCID: PMC2001280

2. Hassanian-Moghaddam H. Phosphides and phosphine: Mechanisms for toxicity and range of the problem. In: XXXIV International Congress of the European Association of Poisons Centres and Clinical Toxicologists (EAPCCT); 27-30 May 2014; Brussels, Belgium. Clin Toxicol 2014;52:397-8.

3. Moghadamnia AA, Abdollahi M. An epidemiological study of poisoning in northern Islamic Republic of Iran. East Mediterr Health J 2002;8:88-94. PMID: 15330564

4. Bogle R, Theron P, Brooks P, Dargan P, Redhead J. Aluminium phosphide poisoning. Emerg Med J 2006;23:e3. doi: 10.1136/emj.2004.015941

5. Gargi J, Rai H, Chanana A, Rai G, Sharma G, Bagga I. Current trends of poisoning-a hospital profile. J Indian Med Assoc 2006;104:72-3, 94. PMID: 16856585

6. Goel A, Aggarwal P. Pesticide poisoning. Natl Med J India 2007;20:182-91. PMID: 18085124

7. Murali R, Bhalla A, Singh D, Singh S. Acute pesticide poisoning: 15 years experience of a large North-West Indian hospital. Clin Toxicol (Phila). 2009;47:35-8. doi: 10.1080/15563650701885807

8. Shadnia S, Sasanian G, Allami P, Hosseini A, Ranjbar A, Amini-Shirazi N, Abdollahi M. A retrospective 7-years study of aluminum phosphide poisoning in Tehran: opportunities for prevention. Hum Exp Toxicol 2009;28:209-13. doi: 10.1177/0960327108097194

9. Nocera A, Levitin HW, Hilton J. Dangerous bodies: a case of fatal aluminium phosphide poisoning. Med J Aust 2000;173:133-5. PMID: 10979378

10. Popp W, Mentfewitz J, Götz R, Voshaar T. Phosphine poisoning in a German office. Lancet 2002;359:1574. doi 10.1016/S0140-6736(02)08518-5

11. Lauterbach M, Solak E, Kaes J, Wiechelt J, Von Mach M-A, Weilemann L. Epidemiology of hydrogen phosphide exposures in humans reported to the poison center in Mainz, Germany, 1983-2003. Clin Toxicol (Phila) 2005;43:575-81. PMID: 16255340

12. Mehrpour O, Singh S. Rice tablet poisoning: a major concern in Iranian population. Hum Exp Toxicol 2010;29:701-2. doi: 10.1177/0960327109359643

13. Hosseinian A, Pakravan N, Rafiei A, Feyzbakhsh SM. Aluminum phosphide poisoning known as rice tablet: a common toxicity in North Iran. Indian J Med Sci 2011;65:1439. doi: 10.4103/0019-5359.104777

14. Hassanian-Moghaddam H, Pajoumand A. Two years epidemiological survey of aluminum phosphide poisoning in Tehran. Iranian J Toxicol 2007;1:35-9.
15. Nosrati A, Karami M, Esmaeilnia M. Aluminum phosphide poisoning: a case series in North Iran. Asia Pac J Med Toxicol 2013;2:111-3.

16. Fumigation (phosphine) explosions. UK P\&I Club [bulletin] 2003;(289). [displayed 9 July 2016]. Available at http://www. ukpandi.com/knowledge/article/289-02-03-fumigationphosphine-explosions-1539/

17. Shadnia S, Soltaninejad K. Spontaneous ignition due to intentional acute aluminum phosphide poisoning. J Emerg Med 2011;40:179-81. doi: 10.1016/j.jemermed.2009.05.028

18. Wahab A, Rabbani MU, Wahab S, Khan RA. Spontaneous self-ignition in a case of acute aluminium phosphide poisoning. Am J Emerg Med 2009;27:752. e5-6. doi: 10.1016/j.ajem.2008.09.045

19. Yadav J, Athawal BK, Dubey BP, Yadav VK. Spontaneous ignition in case of celphos poisoning. Am J Forensic Med Pathol 2007;28:353-5. doi: 10.1097/PAF.0b013e31815b4bed

20. NIOSH, ALERT. Preventing Phosphine Poisoning and Explosions during Fumigation [displayed 10 August 2016]. Available at https://www.cdc.gov/niosh/docs/99-126/ pdfs/99-126.pdf

21. Mehrpour O, Jafarzadeh M, Abdollahi M. A systematic review of aluminium phosphide poisoning. Arh Hig Rada Toksikol 2012;63:61-73. doi: 10.2478/10004-1254-63-20122182

22. Pepelko B, Seckar J, Harp PR, Kim JH, Gray D, Anderson EL. Worker exposure standard for phosphine gas. Risk Anal 2004;24:1201-13. doi: 10.1111/j.0272-4332.2004.00519.x

23. International Program on Chemical Safety (IPCS). Phosphine (PIM 865). Poisons information monograph [displayed 10 August 2016]. Available at http://www.inchem.org/ documents/pims/chemical/pim865.htm

24. Anger F, Paysant F, Brousse F, Le Normand I, Develay P, Galliard Y, Baert A, Le Gueut MA, Pepin G, Anger JP. Fatal aluminum phosphide poisoning. J Anal Toxicol 2000;24:902. PMID: 10732945

25. Mehrpour O, Alfred S, Shadnia S, Keyler D, Soltaninejad K, Chalaki N, Sedaghat M. Hyperglycemia in acute aluminum phosphide poisoning as a potential prognostic factor. Hum Exp Toxicol 2008;27:591-5. doi: 10.1177/0960327108096382

26. Gurjar M, Baronia AK, Azim A, Sharma K. Managing aluminum phosphide poisonings. J Emerg Trauma Shock 2011;4:378-84. doi: 10.4103/0974-2700.83868

27. Dua R, Gill KD. Effect of aluminium phosphide exposure on kinetic properties of cytochrome oxidase and mitochondrial energy metabolism in rat brain. Biochim Biophys Acta 2004;1674:4-11. doi: 10.1016/j.bbagen.2004.05.003

28. Singh S, Bhalla A, Verma SK, Kaur A, Gill K. Cytochrome-C oxidase inhibition in 26 aluminum phosphide poisoned patients. Clin Toxicol (Phila) 2006;44:155-8. doi: 10.1080/15563650500514467

29. Hsu C-H, Chi B-C, Liu M-Y, Li J-H, Chen C-J, Chen R-Y. Phosphine-induced oxidative damage in rats: role of glutathione. Toxicology 2002;179:1-8. doi: 10.1016/S0300483X(02)00246-9

30. Lall SB, Peshin S, Mitra S. Methemoglobinemia in aluminium phosphide poisoning in rats. Idian J Exp Biol 2000;38:95-7. PMID: 11233095

31. Proudfoot AT. Aluminium and zinc phosphide poisoning. Clin Toxicol (Phila) 2009;47:89-100. doi: $10.1080 / 15563650802520675$ 
32. Anand R, Binukumar BK, Gill KD. Aluminum phosphide poisoning: an unsolved riddle. J Appl Toxicol 2011;31:499505. doi: $10.1002 /$ jat. 1692

33. Mittra S, Peshin S, Lall S. Cholinesterase inhibition by aluminium phosphide poisoning in rats and effects of atropine and pralidoxime chloride. Acta Pharmacol Sin 2001;22:37-9. PMID: 11730559

34. Shadnia S, Soltaninejad K, Hassanian-Moghaddam H, Sadeghi A, Rahimzadeh H, Zamani N, Ghasemi-Toussi A, Abdollahi M. Methemoglobinemia in aluminum phosphide poisoning. Hum Exp Toxicol 2011;30:250-3. doi: 10.1177/0960327110384287

35. Mashayekhian M, Hassanian-Moghaddam H, Rahimi M, Zamani N, Aghabiklooei A, Shadnia S. Elevated carboxyhemoglobin concentrations by pulse CO-oximetry is associated with severe aluminium phosphide poisoning. Basic Clin Pharmacol Toxicol 2016;119:322-9. doi: 10.1111/ bcpt. 12571

36. Moazezi Z, Abedi SH. A successful management of aluminum phosphide intoxication. Caspian J Int Med 2011;2:286-8. PMCID: PMC3770497

37. Moghadamnia AA. An update on toxicology of aluminum phosphide. Daru 2012;20:25. doi: 10.1186/2008-2231-20-25

38. Sudakin D. Occupational exposure to aluminium phosphide and phosphine gas? A suspected case report and review of the literature. Hum Exp Toxicol 2005;24:27-33. doi 10.1191/0960327105ht496oa

39. Louriz M, Dendane T, Abidi K, Madani N, Abouqal R, Zeggwagh AA. Prognostic factors of acute aluminum phosphide poisoning. Indian J Med Sci 2009;63:227-34. doi: 10.4103/0019-5359.53386

40. Frangides CY, Pneumatikos IA. Persistent severe hypoglycemia in acute zinc phosphide poisoning. Intensive Care Med 2002;28:223. doi: 10.1007/s00134-001-1164-7

41. Akkaoui M, Achour S, Abidi K, Himdi B, Madani A, Zeggwagh AA, et al. Reversible myocardial injury associated with aluminum phosphide poisoning. Clin Toxicol (Phila) 2007;45:728-31. doi: 10.1080/15563650701517350

42. Bayazit AK, Noyan A, Anarat A. A child with hepatic and renal failure caused by aluminum phosphide. Nephron 2000;86:517. doi: $10.1159 / 000045849$

43. Memiş D, Tokatlıoglu D, Koyuncu O, Hekimoglu S. Fatal aluminium phosphide poisoning. Eur J Anaesthesiol 2007;24(03):292-3.

44. Saleki S, Ardalan FA, Javidan-Nejad A. Liver histopathology of fatal phosphine poisoning. Forensic Sci Int 2007;166:1903. doi: 10.1016/j.forsciint.2006.05.033

45. Kaushik RM, Kaushik R, Mahajan SK. Subendocardial infarction in a young survivor of aluminium phosphide poisoning. Hum Exp Toxicol 2007;26:457-60. doi: 10.1177/0960327107074618

46. Mehrpour O, Farzaneh E, Abdollahi M. Successful treatment of aluminum phosphide poisoning with digoxin: A case report and review of literature. Int J Pharmacol 2011;7:761-4. doi: 10.3923/ijp.2011.761.764

47. Alter P, Grimm W, Maisch B. Lethal heart failure caused by aluminium phosphide poisoning. Intensive Care Med 2001;27:327. PMID: 11280664

48. Mehrpour O, Shadnia S, Soltaninejad K, Yaghmaei A. Evaluation of electrolytes and blood glucose level in aluminum phosphide poisoning. Sci J Forensic Med 2009;15:49-53.
49. Chugh S, Kishore K, Aggarwal N, Attri S. Aluminium phosphide (ALP) is a widely used fumigant posticide. J Assoc Physicians India 2000;48:855-6. PMID: 11273495

50. Shadnia S, Mehrpour O, Abdollahi M. Unintentional poisoning by phosphine released from aluminum phosphide. Hum Exp Toxicol 2008;27:87-9. doi: 10.1177/0960327107086241

51. Verma S, Ahmad S, Shirazi N, Barthwal S, Khurana D, Chugh M, Gambhir HS. Acute pancreatitis: A lesser-known complication of aluminum phosphide poisoning. Hum Exp Toxicol 2007;26:979-81. doi: 10.1177/0960327107087793

52. Jain RK, Gouda NB, Sharma VK, Dubey TN, Shende A, Malik R, Tiwari G. Esophageal complications following aluminium phosphide ingestion: An emerging issue among survivors of poisoning. Dysphagia 2010;25:271-6. doi: 10.1007/s00455-009-9251-y

53. Madan K, Chalamalasetty SB, Sharma M, Makharia G. Corrosive-like strictures caused by ingestion of aluminium phosphide. Natl Med J India 2006;19:313-4. PMID: 17343015

54. Verma R, Gupta S, Bahl D, Gupta A. Aluminium phosphide poisoning: late presentation as oesophageal stricture. JK Sci 2006;8:235-6

55. Okolie NP, Aligbe JU, Osakue EE. Phostoxin-induced biochemical and pathomorphological changes in rabbits. Indian J Exp Biol 2004;42:1096-9. PMID: 15587116

56. Srivastava A, Peshin SS, Kaleekal T, Gupta SK. An epidemiological study of poisoning cases reported to the National Poisons Information Centre, All India Institute of Medical Sciences, New Delhi. Hum Exp Toxicol 2005;24:27985. doi: 10.1191/0960327105ht527oa

57. Chugh SN, Kishore K, Aggarwal N, Attri S. Hypoglycemia in acute aluminium phosphide poisoning. J Assoc Physicians India 2000;48:855-6.

58. Khurana V, Gambhir I, Kishore D. Microangiopathic hemolytic anemia following disseminated intravascular coagulation in aluminum phosphide poisoning. Indian J Med Sci 2009;63:257-9. doi: 10.4103/0019-5359.53396

59. Soltaninejad K, Nelson LS, Khodakarim N, Dadvar Z, Shadnia S. Unusual complication of aluminum phosphide poisoning: Development of hemolysis and methemoglobinemia and its successful treatment. Indian J Crit Care Med 2011:15:117-9. doi: 10.4103/0972-5229.83021

60. Mehrpour O, Dolati M, Soltaninejad K, Shadnia S, Nazparvar B. Evaluation of histopathological changes in fatal aluminum phosphide poisoning. Indian J Forensic Med Toxicol 2008;2:34-6.

61. Soltaninejad K, Beyranvand M-R, Momenzadeh S-A, Shadnia S. Electrocardiographic findings and cardiac manifestations in acute aluminum phosphide poisoning. $\mathrm{J}$ Forensic Leg Med 2012;19:291-3. doi: 10.1016/j. jflm.2012.02.005

62. Hassanian-Moghaddam H, Zamani N. Therapeutic role of hyperinsulinemia/euglycemia in aluminum phosphide poisoning. Medicine 2016;95(31):e4349.

63. Soltaninejad K, Shadnia S, Ziyapour B, Brent J. Aluminum phosphide intoxication mimicking ischemic heart disease led to unjustified treatment with streptokinase. Clin Toxicol (Phila) 2009;47:908-9. doi: 10.3109/15563650903285657

64. National Research Council (US) Committee on Acute Exposure Guideline Levels. Phosphine and eight metal phosphides. In: Acute exposure guideline levels for delected 
airborne chemicals. Vol. 6. Washington (DC): National Academics Press; 2008. p. 73.

65. Chan LT, Crowley RJ, Delliou D, Geyer R. Phosphine analysis in post mortem specimens following ingestion of aluminium phosphide. J Anal Toxicol 1983 JulAug;7(4):165-7.

66. Hassanian-Moghaddam $\mathrm{H}$, Shahnazi M, Zamani N, BahramiMotlagh $\mathrm{H}$. Abdominal imaging in zinc phosphide poisoning. Emerg Radiol 2014;21:329-31. doi: 10.1007/s10140-0141195-3

67. Hassanian-Moghaddam H, Shahnazi M, Zamani N, Rahimi M, Bahrami-Motlagh $\mathrm{H}$, Amiri H. Plain abdominal radiography: A powerful tool to prognosticate outcome in patients with zinc phosphide poisoning. Clin Radiol 2014;69:1062-5. doi: 10.1016/j.crad.2014.06.003

68. Maitai C, Njoroge D, Abuga K, Mwaura A, Munenge R. Investigation of possible antidotal effects of activated charcoal, sodium bicarbonate, hydrogen peroxide and potassium permanganate in zinc phosphide poisoning. East Central Afr J Pharm Sci 2004;5:38-41. doi: 10.4314/ecajps. v5i2.9686

69. Jalali N, Shadnia S, Abdofiahi M, Pajoumand A. Survival following severe aluminium phosphide poisoning. J Pharm Pract Res 2002;32:297-9. doi: 10.1002/jppr2002324297

70. Shadnia S, Rahimi M, Pajoumand A, Rasouli M-H, Abdollahi M. Successful treatment of acute aluminium phosphide poisoning: possible benefit of coconut oil. Hum Exp Toxicol 2005;24:215-8. PMID: 15957538

71. Saidi H, Shojaie S. Effect of sweet almond oil on survival rate and plasma cholinesterase activity of aluminum phosphide-intoxicated rats. Hum Exp Toxicol 2012;31:51822. doi: $10.1177 / 0960327111407229$

72. Hassanian-Moghaddam H, Shahbazi A. Gastric ventilation: a new approach to metal phosphide fumigant ingestion. Clin Toxicol (Phila) 2012;50:435-7. doi: $10.3109 / 15563650.2012 .676648$

73. Sanaei-Zadeh $\mathrm{H}$, Farajidana $\mathrm{H}$. Is there a role for digoxin in the management of acute aluminum phosphide poisoning? Med Hypotheses 2011;76:765-6. doi: 10.1016/j. mehy.2011.02.023

74. Mehrpour O, Amouzeshi A, Dadpour B, Oghabian Z, Zamani N, Amini S, Hoffman RS. Successful treatment of cardiogenic shock with an intraaortic balloon pump following aluminium phosphide poisoning. Arh Hig Rada Toksikol 2014;65:1217. doi: 10.2478/10004-1254-65-2014-2393

75. Hassanian-Moghaddam H, Zamani N, Rahimi M, Hajesmaeili M, Taherkhani M, Sadeghi R. Successful treatment of aluminium phosphide poisoning by extracorporeal membrane oxygenation. Basic Clin Pharmacol Toxicol 2016;118:243-6. doi: 10.1111/bcpt.12481

76. Baud FJ, Megarbane B, Deye N, Leprince P. Clinical review: aggressive management and extracorporeal support for druginduced cardiotoxicity. Crit Care 2007;11:207. doi: 10.1186/ $\operatorname{cc} 5700$

77. Wiki Tox - Open Source Clinical Toxicology Curriculum. Phosphorus and phosphides. Phosphides/Phosphine gas [displayed 10 August 2016]. Avalable at http://curriculum. $\mathrm{t}$ o $\mathrm{x}$ i c o l o g y. w i k i s p a c e s. net/2.2.10.30+Phosphorus+and+phosphides
78. Azad A, Lall S, Mittra S. Effect of N-acetylcysteine and L-NAME on aluminium phosphide induced cardiovascular toxicity in rats. Acta Pharmacol Sin 2001;22:298-304. PMID: 11742581

79. Tehrani H, Halvaie Z, Shadnia S, Soltaninejad K, Abdollahi M. Protective effects of $\mathrm{N}$-acetylcysteine on aluminum phosphide-induced oxidative stress in acute human poisoning. Clin Toxicol (Phila) 2013;51:23-8. doi: 10.3109/15563650.2012.743029

80. Agarwal A, Robo R, Jain N, Gutch M, Consil S, Kumar S. Oxidative stress determined through the levels of antioxidant enzymes and the effect of $\mathrm{N}$-acetylcysteine in aluminum phosphide poisoning. Indian J Crit Care Med 2014;18:66671. doi: $10.4103 / 0972-5229.142176$

81. Saidi H, Shokraneh F, Ghafouri H-B, Shojaie S. Effects of hyperbaric oxygenation on survival time of aluminum phosphide intoxicated rats. J Res Med Sci 2011;16:1306-12. PMCID: PMC3430020

82. Marashi SM, Arefi M, Behnoush B, Nasrabad MG, Nasrabadi $\mathrm{ZN}$. Could hydroxyethyl starch be a therapeutic option in management of acute aluminum phosphide toxicity? Med Hypotheses 2011;76:596-8. doi: 10.1016/j.mehy.2011.01.009

83. Zamani N, Mehrpour O. Protective role of G6PD deficiency in poisoning by aluminum phosphide; are there possible new treatments? Eur Rev Med Pharmacol Sci 2013;17:994-5. PMID: 23640450

84. Wahab A, Zaheer M, Wahab S, Khan R. Acute aluminium phosphide poisoning: an update. Hong Kong J Emerg Med 2008:15:152-5.

85. Shadnia S, Mehrpour O, Soltaninejad K. A simplified acute physiology score in the prediction of acute aluminum phosphide poisoning outcome. Indian J Med Sci 2010;64:5329. doi: $10.4103 / 0019-5359.75928$

86. Mostafazadeh B, Pajoumand A, Farzaneh E, Aghabiklooei A, Rasouli MR. Blood levels of methemoglobin in patients with aluminum phosphide poisoning and its correlation with patient's outcome. J Med Toxicol 2011;7:40-3. doi: 10.1007/ s13181-010-0121-7

87. Alizadeh AM, Hassanian-Moghaddam H, Shadnia S, Zamani N, Mehrpour O. Simplified acute physiology score II/acute physiology and chronic health evaluation II and prediction of the mortality and later development of complications in poisoned patients admitted to intensive care unit. Basic Clin Pharmacol Toxicol 2014;115:297-300. doi: 10.1111/ bcpt. 12210

88. Bhargava S, Rastogi R, Agarwal A, Jindal G. Esophagobronchial fistula-A rare complication of aluminum phosphide poisoning. Ann Thorac Med 2011;6:41-2. doi: 10.4103/1817-1737.74276

89. Levels of Evidence and grades of recommendation: SIGN [displayed 11 August 2016]. Available at http://www. guiasalud.es/egpc/traduccion/ingles/parto_normal/completa/ documentos/apartado00/levels_of_evidence.pdf

90. Krishan Vij. Textbook of forensic medicine and toxicology: Principles and practice. 5 th ed. Chapter 44. Fumigants. New Delhi: Elsevier, a division of Reed Elsevier India Private Limited; 2014. p. 541-5. 


\section{Pregled otrovanja aluminijevim fosfidom i prijedlog dijagrama tijeka njegova liječenja}

Primjena pesticida poput aluminijeva fosfida (AlP) raste iz godine u godinu, povoljno utječući na količinu i kakvoću poljoprivrednih proizvoda u mnogim zemljama u razvoju. Nažalost, AlP može uzrokovati i snažne kronične i akutne zdravstvene posljedice, koje su u zemljama poput Indije, Irana, Bangladeša i Jordana dosegnule zabrinjavajuće razmjere. U svijetu svake godine od otrovanja pesticidima umre gotovo 300.000 ljudi. Mnoge od tih smrti uzrokovane su aluminijevim fosfidom. Svrha je ovoga članka dati kratak pregled literature vezane uz otrovanje AlP-om te predložiti algoritam njegova liječenja koji se temelji na dosadašnjim spoznajama. U tu smo svrhu pregledali sve članke o liječenju otrovanja AlP-om od 2000. naovamo. Oslanjajući se na prilagođeni Delphi-dizajn, osmislili smo koristan dijagram tijeka koji bi se mogao koristiti kao vodič kroz liječenje otrovanja aluminijevim fosfidom u hitnim službama.

KLJUČNE RIJEČI: hitna služba; liječenje otrovanja; pesticidi; pregled literature 